\title{
O DISCURSO DO PROGRESSO E A EDUCAÇÃO NA HISTÓRIA DE SINOP - MATO GROSSO: "COMO É BOM ALARGAR FRONTEIRAS DE NOSSA PÁTRIA!"1
}

DOI: http://dx.doi.org/10.1590/2236-3459/67292

\author{
Cristinne Leus Tomé \\ Universidade do Estado de Mato Grosso, Brasil. \\ Josiane Brolo Rohden \\ Universidade Federal de Rondônia, Brasil.
}

$\cos 80$

\begin{abstract}
Resumo
Este artigo aborda o entrelaçamento do discurso do progresso na educação sinopense dentro do contexto de implementação da política de integração nacional entre os anos de 1973 e 1979. O discurso de progresso difundido pelo Governo Federal foi assumido pelos Colonizadores, pelos migrantes e pela escola, que em suas práticas exemplificou e manifestou todos os valores desenvolvimentistas da época. A fundamentação teórica se baseou nas contribuições de Michel de Certeau e a pesquisa empírica foi realizada a partir dos procedimentos da História Oral com entrevistas com ex-professoras, assim como em documentos, revistas, iconografias localizadas em acervos particulares e públicos.

Palavras-chave: educação escolar, processo colonizador, discurso do progresso, Sinop.
\end{abstract}

\section{EL DISCURSO DEL PROGRESO Y LA EDUCACIÓN EN LA EN LA HISTORIA DE HISTÓRIA DE SINOP - MATO GROSSO: "COMO ES BUENO EXPANDIR LAS FRONTERAS DE NUESTRA PATRIA!"}

\begin{abstract}
Resumen
En este artículo se realiza la articulación del discurso del progreso en la educación sinopense en el contexto de la aplicación de la política nacional de integración entre los años 1973 y 1979 . El discurso de progreso transmitido por el Gobierno Federal fue tematizado por los colonos, los migrantes y la escuela, ejemplificado en sus prácticas y expresó los valores del desarrollo de la época. El marco teórico se basa en Michel de Certeau y la investigación empírica fue por procedimientos de la Historia Oral, entrevistas con antiguos profesores, así como documentos, revistas, iconografía situadas en colecciones públicas y privadas.

Palabras clave: educación escolar, proceso colonizador, discurso del progreso, Sinop.
\end{abstract}

${ }^{1}$ Verso do poema escrito pelo Colonizador Enio Pipino publicado em 1979. 
THE PROGRESS AND EDUCATION IN HISTORY OF SINOP - MATO GROSSO: "IT'S GOOD TO EXPAND BORDERS OF OUR FATHERLAND"

\section{Abstract}

This article brings up the intertwining of progress' speech and the Sinop education in the State of Mato Grosso, between the years of 1973 and 1979. The speech of widespread progress by the Federal Government was taken over by the Settlers, by migrants and by the school, which in its practices exemplified and expressed all developmental values of the time. The theoretical basis is on the contributions of Michel de Certeau and the empirical research was conducted from the procedures of Oral History with interviews with ex-teachers, as well as documents, magazines, Iconographies, located in private and public piles.

Keywords: school education, colonization process, speech progress, Sinop.

\section{LE DISCOURS DU PROGRÈS ET L'ÉDUCATION DANS L'HISTOIRE DE SINOP - MATO GROSSO: "COMME IL EST BON D'ELARGIR LES FRONTIERES DE NOTRE PATRIE!"}

\section{Résumé}

Cet article traite de l'entremèlement du discours du progrès dans l'éducation sinopense dans le contexte de la mise en œuvre de la politique d'intégration nationale entre les années 1973 et 1979. Le discours de progrès diffusé par le gouvernement fédéral a été repris par les colonisateurs, les migrants et l'école, que dans leurs pratiques ont illustré et exprimé toutes les valeurs de développement de l'époque. Le cadre théorique a été basé sur les contributions de Michel de Certeau et la recherche empirique a été réalisée sur les procédures de l'Histoire Orale en interviewant d' anciens enseignants, ainsi que des documents, des magazines, desiconographies, situé dans des collections privées et publiques .

Mots-clés: éducation scolaire, processus de colonisation, discours du progrès, Sinop. 


\section{Introdução}

$\mathrm{N}$

este trabalho procuramos discutir a relação entre o discurso do progresso e a educação na cidade de Sinop, no Mato Grosso, durante a implementação da política de integração nacional do Governo Federal na década de 70 do século passado. Esta política objetivou ocupar os espaços demográficos considerados não habitados da região Amazônia com a vinda de migrantes de outros estados.

A cidade de Sinop foi fruto desta política de integração nacional. Nasceu a partir de um projeto de colonização privada empreendido pela empresa Colonizadora Sinop S. A. ${ }^{2}$, proprietária de uma extensa área na região norte de Mato Grosso, denominada Gleba Celeste, a $500 \mathrm{~km}$ da capital Cuiabá, no município de Chapada dos Guimarães, conforme Portaria do INCRA № 1.553/1972³. Nesta área foram construídas quatro cidades: Vera, Sinop, Santa Carmem e Cláudia (STRAUB, 2015).

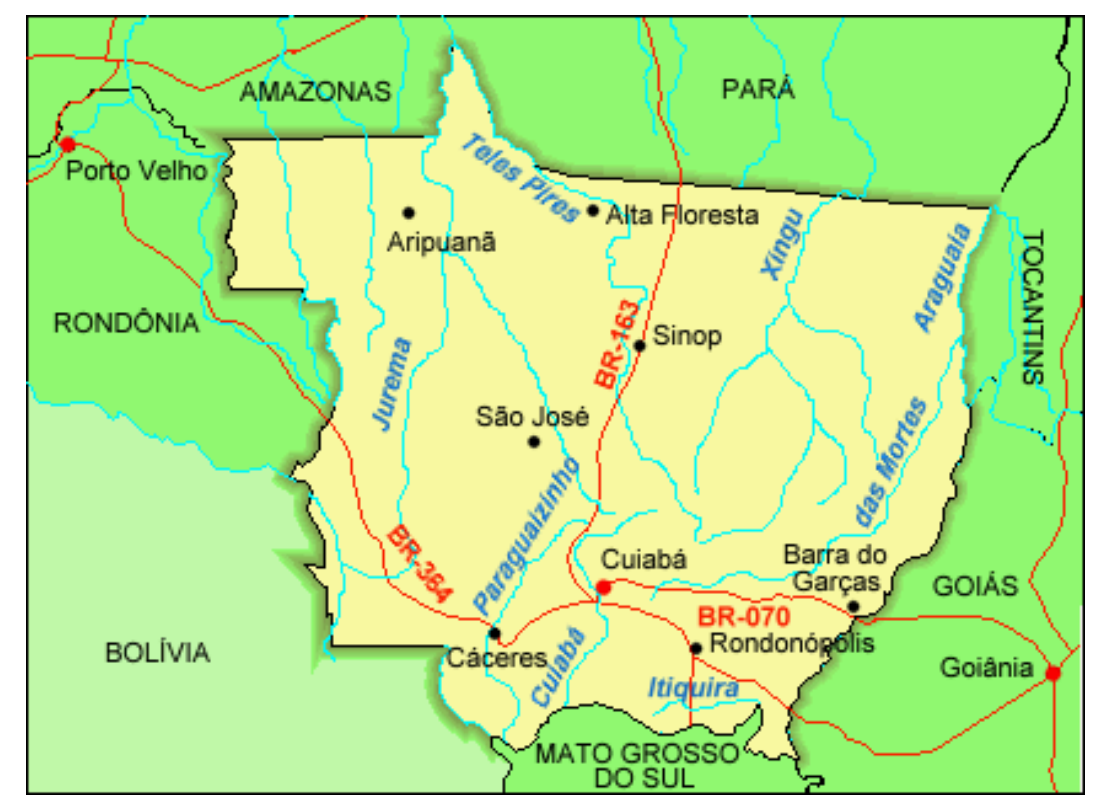

Figura 1 - Mapa do estado de Mato Grosso.

Fonte: Só Geografia, acervo particular, 2017.

Em 1970 a empresa Colonizadora, de propriedade de Enio Pipino e João Pedro Moreira de Carvalho, iniciou o reconhecimento do local por via aérea ou fluvial e, em 1971, uma equipe de trabalhadores chefiados pelo topógrafo Ulrich Grabert e pelo agrimensor Carlos Benito Spadoni vieram com a finalidade de abrir as cidades de Vera, Santa Carmem e Sinop (SANTOS, 2007, p. 29). Concomitantemente, a empresa iniciou um movimento publicitário a fim de atrair colonos da Região Sul do país, principalmente do Estado do Paraná onde já tinha experiência em colonização, para migrarem e trabalharem com o cultivo de terras (inicialmente a cafeicultura).

Faz-se necessário mencionar que a delimitação do período deste estudo será entre os anos de 1973 a 1979, período em que Sinop pertenceu ao município de Chapada dos Guimarães. O início do processo de implementação da educação escolar foi instituído

2 Sinop - Sociedade Imobiliária do Noroeste do Paraná.

${ }^{3}$ Conforme Panosso Netto, 2000. 
em 1973, sendo a escola uma extensão da Escola Estadual Nossa Senhora do Perpétuo Socorro de Vera. Oficialmente a cidade de Sinop foi fundada no ano seguinte, em 14 de setembro de 1974 e, em 17 de dezembro de 1979, passou, então, a município. Nas imagens a seguir temos a abertura da cidade em 1972 e uma foto de toda a cidade em 1979.

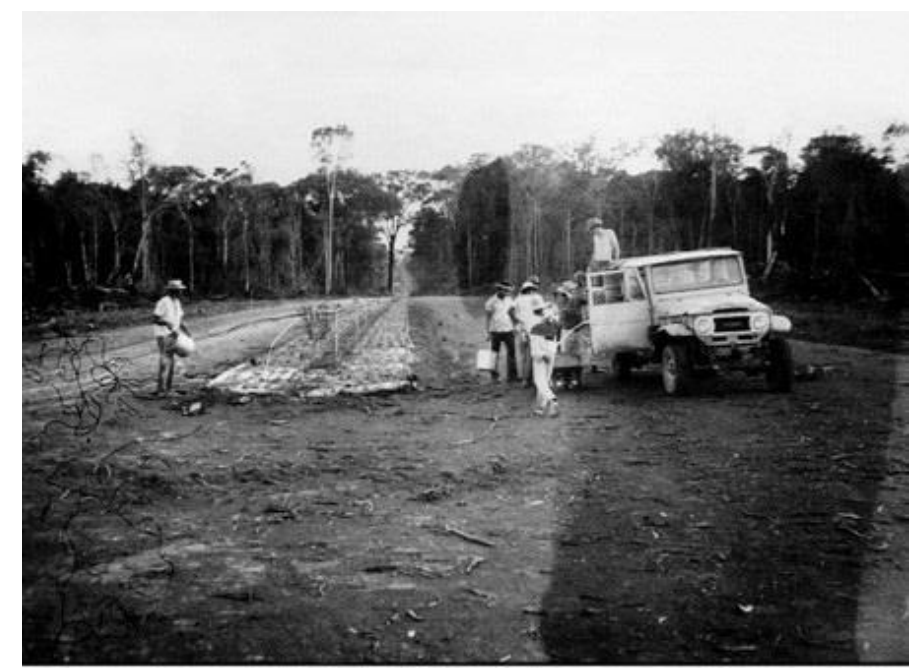

Figura 2 - Abertura da avenida principal da cidade de Sinop.

Fonte: Colonizadora Sinop S. A., Acervo Particular, 1972.

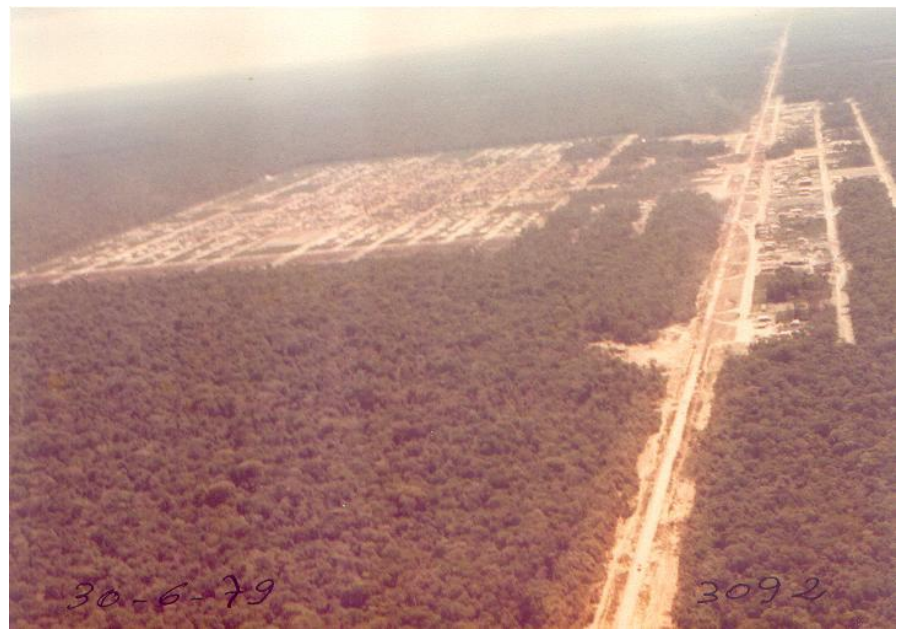

Figura 3 - Vista aérea de Sinop.

Fonte: Colonizadora Sinop S. A., Acervo Particular, 30 jun. 1979.

Para a construção deste artigo nos voltamos às fontes históricas da colonização e das origens da educação localizadas em acervos particulares e públicos. Além das fontes analisadas, adotou-se os procedimentos metodológicos da História Oral, com entrevistas com ex-professores da escola que compuseram o cotidiano passado deste estudo.

Para a escrita desta história levamos em consideração de que, como constata Certeau (2007), não se pode falar de uma história absoluta, mas de perspectivas subjugadas aos limites das pesquisas históricas e influenciadas pelo presente do historiador. A história não reconstitui a verdade dos acontecimentos ocorridos no 
passado, mas se consolida em uma operação historiográfica, na qual reforça o sentido de se constituir como apenas uma versão, uma vez que:

A história está, pois, em jogo nessas fronteiras [entre um objeto passado e uma práxis presente] que articulam uma sociedade com o seu passado e o ato de distinguir-se dele; nessas linhas que traçam a imagem de uma atualidade, demarcando-a de seu outro, mas que atenua ou modifica, continuamente, o retorno do "passado". (CERTEAU, 2007, p. 48)

A propósito de "traçar a imagem de uma atualidade", este artigo foi organizado em três momentos que tem como discussão principal o discurso do progresso. Primeiramente, com o título $O$ processo de colonização e o discurso do progresso: 0 espírito bandeirante presente na história de Sinop, propomos uma contextualização histórica de Sinop, o projeto de colonização dentro do Plano Nacional de Desenvolvimento do Governo Federal e a imagem que se desenhou aos Colonizadores como os modernos bandeirantes que alargaram as fronteiras (internas) brasileiras.

Ao reunirmos os fatos que constituíram a história da educação em Sinop em sua identificação com o discurso do progresso, notamos que os sentidos enunciados pelo discurso desbravador das bandeiras no período colonial foram retomados pelas empresas colonizadoras, em especial a Sinop S. A. No caso exemplificativo abaixo, o Ministro da Agricultura Alysson Paulinelli referiu-se ao "moderno bandeirante" ao dirigir-se ao Colonizador Enio Pipino, em reportagem do jornal O Estado do Paraná (15 maio 1975, p. 8).

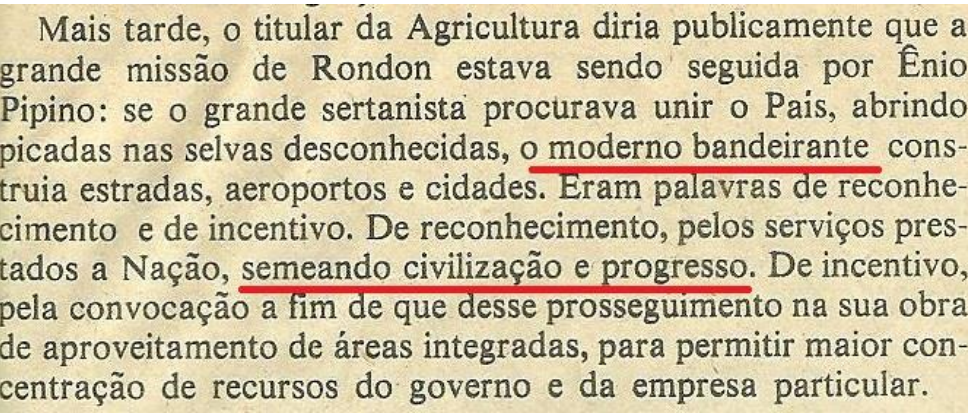

Figura 4 - Enio Pipino: o moderno bandeirante.

Fonte: O Estado do Paraná, 15 maio 1975.

Sentidos sobre este moderno bandeirante passaram a estar presentes nas falas dos colonos que chegaram e se identificaram com a proposta de integrar as áreas "semeando civilização e progresso". Assim, nosso próximo capítulo teve como título $O$ sujeito migrante e o discurso do progresso: "a Gleba Celeste acena para o Brasil como novo mundo de riquezas"4. A imagem do progresso, como um ideal conquistado pelos colonos e suas famílias, sujeitos representantes que participaram do crescimento econômico da cidade, é enfático em suas memórias. O sujeito migrante, que é apresentado como o novo bandeirante do século XX, superou todas as dificuldades encontradas no início da colonização para desfrutar de uma cidade que ele próprio ajudou a fundar, como nos lembra a família Trierweiler (SANTOS, 2007, p. 59, grifo nosso):

${ }_{4}^{4}$ Palavras ditas pelo Colonizador Enio Pipino, 1979. 
Os anos foram passando, as dificuldades foram sendo superadas e os objetivos aos poucos foram sendo alcançados e hoje a família Trierweiler tem orgulho de dizer aos filhos, aos netos e a quem chegou depois, que valeu a pena, pois não existe recompensa maior do que poder dizer: eu ajudei a construir a História desta cidade que faz parte da minha história.

O discurso do progresso que se constituiu a partir das vivências do sujeito migrante está marcado por modificações sociais que contribuíram para que antigas experiências de desgostos e necessidades, feridas históricas, fossem esquecidas e substituídas pelo reconhecimento de prosperidade atual.

Finalizamos com o título $A$ educação e o discurso do progresso: "porque se não tivesse escola para os filhos, o povo não ficava", onde tecemos um diálogo das relações entre educação e progresso de modo a inferir que a educação escolar serviu como ferramenta para fixação do migrante ao lugar entre 1973 e 1979.

As práticas cotidianas escolares em Sinop estavam entrelaçadas ao discurso do progresso propagado por todo o país. Ideais patrióticos era assunto de atividades escolares anuais, estudados nas disciplinas, destacados em festas comemorativas, assim como ideais ético-morais, instigados por comportamentos de obediência aos superiores, amor à Pátria, trabalho e fé. Para tanto, convidamos o leitor a conhecer e refletir sobre as discussões apresentadas neste trabalho.

\section{O processo de colonização e o discurso do progresso: o espírito bandeirante presente na história de Sinop}

[...] sempre foi um crescimento acelerado, até me assusta! Me parece que Sinop não nasceu, ela explodiu!

(BRAZ, depoimento 8 dez. 2011)

A epígrafe desta seção relata de modo considerável o discurso da história de Sinop, que enfatizou e enfatiza o mito do progresso. No passado, um slogan que marcou a localidade dizia: "a cidade menina que logo se transformará em metrópole da Amazônia"6 e, no momento presente, é reconhecida por seu progresso avassalador: "Sinop - a capital do Nortão"7. De cidade menina à metrópole capital do Nortão foram apenas 40 anos.

Como um mito ufanista urbano, circula na sociedade sinopense de que a mesma "não nasceu, ela explodiu!", o discurso de progresso, tão pontuado no passado para atrair migrantes, ainda prolifera no presente, com a chegada de pessoas das mais diferentes regiões do país. A busca por melhores condições de vida depositadas em uma localidade física, como se fora um Eldorado, foi fomentada antigamente pela extração da madeira na floresta e pelo plantio do café e, atualmente, o foco direcionou-se para o agronegócio e suas possibilidades de empregos nos setores agrícolas, industriais e urbanos em geral.

O processo de colonização da Gleba Celeste foi definido a partir de dois grandes planos nacionais que consistiram em promover o crescimento do Brasil, colocando-o no

${ }^{5}$ Palavras retiradas do depoimento da Professora Maria Augusta de Paula em 02 fev. 2012.

6 Slogan de uma faixa exposta na fundação de Sinop em 14 de Setembro de 1974. REVISTA NOTíCIA DO ESTADO DE MATO GROSSO. Sinop 37 anos. Porto Alegre: PRC LTDA, ed. 106, Ano XVII, out. 2011.

7 REVISTA VEJA, 2010. A capital do Nortão (reportagem) - Matéria Especial: as 20 metrópoles brasileiras do futuro. São Paulo: Abril, n. 2.180, p. 72, 01 set. 2010. 
mesmo nível que as grandes potências mundiais: o primeiro, no governo do General Emílio Garrastazu Médici I Plano Nacional de Desenvolvimento (I PND - 1972-1974) e o segundo, o II PND, lançado em dezembro de 1974, pelo presidente General Ernesto Geisel (1974-1979). O presidente Geisel ressaltou na ocasião que "O objetivo maior de todo o planejamento nacional é o homem brasileiro, nas suas diferentes dimensões e aspirações" (O ESTADO DO PARANÁ, 15 maio 1975, p. 8).

Neste movimento de crescimento e ocupação do interior do Brasil pelo "homem brasileiro", a empresa Colonizadora Sinop S. A. assumiu a responsabilidade de todo o empreendimento na Gleba Celeste, como as obras de infraestrutura, medição e demarcação das terras, abertura de estradas vicinais, implantação de núcleos urbanos, instalações de serviço de saúde, educação, ações sociais e comerciais. Em contrapartida, a empresa recebeu apoio dos órgãos federais e estaduais na construção de rodovias, estradas, incentivos fiscais e políticas públicas. O II PND, por exemplo, previa um eixo viário que possibilitasse o fluxo entre as novas cidades criadas e os migrantes sulistas, para "a conquista da Amazônia e do Centro-Oeste, com a utilização dos eixos naturais de penetração, neste caso, através da BR 163, fluxo originário do Sul, como idealizava Rondon e como comprovava a realidade brasileira" (O ESTADO DO PARANÁ, 15 maio 1975, p. 8).

Assim, em parceria com os Governos Estadual e Federal, estes foram os maiores responsáveis pela efetivação da colonização das chamadas 'áreas de fronteira'. Segundo Teixeira (2006, p. 13, grifo da autora) tal expansão da fronteira:

[...] se constituía, para o Estado, num meio de garantir a posse do território e de controlar sua população. Desse modo, ao longo de toda a história do Brasil, o processo de ocupação se deu por etapas que "obedeciam" um movimento de leste para oeste, impulsionado pela produção de matérias-primas voltadas para o mercado externo.

Ainda de acordo com a autora supracitada, esse processo de ocupação da região norte de Mato Grosso trouxe, por um lado, um significativo crescimento econômico no local, entretanto, a custas de grandes impactos sociais e ambientais, não só na área de seu entorno, como também na dinâmica econômica de outros estados do país.

Muitos migrantes - colonos, investidores individuais ou empresariais, estimulados pelas propagandas e incentivos do Governo Federal se voltaram para a conquista de novos territórios na busca de um futuro promissor economicamente. Vieram da Região Sul grande parte desses migrantes atraídos pelo baixo valor das terras e pela publicidade "Em terra livre de geada"8, uma típica referência ao clima inóspito da Região Sul do Brasil, onde a geada matinal queimava plantações inteiras sem que o agricultor tivesse meios de uma proteção mais eficaz.

Faz-se necessário pontuar que, para que a construção da cidade de Sinop pudesse ser consolidada, a região já havia sido aberta e limpa pela frente de expansão, isto é, "uma frente humana que foi desbravando e reconhecendo a região antes da chegada do grande capital" (SIQUEIRA; COSTA; CARVALHO, 1990, p. 262). Essa frente previamente fez o trabalho de preparar a terra para torná-la propícia à colonização, afastando aqueles que não eram desejados naquele lugar, como os índios Kayabi e os

${ }^{8}$ Colonizadora Sinop S. A. Panfleto Publicitário. Década de setenta e oitenta. 
seringueiros (Souza, 2006), que já habitavam tal localidade. Para administrar o projeto de colonização o Governo Federal preferiu convidar o empresário sulista devido à sua tradição em fundar cidades, organizar o translado e a fixação de trabalhadores que conheciam o cultivo da terra. De acordo com Arruda (1997, p. 36, grifo do autor):

\begin{abstract}
Os empresários do Centro-Sul [...] foram efetivamente os escolhidos pelo regime militar para reencarnar o espírito bandeirante, conhecedor e explorador dos sertões, a fim de levar adiante o projeto de colonização privada, ressuscitando dessa forma o projeto que tinha o propósito de ocupar e desenvolver os "espaços vazios" da Amazônia, como pontos avançados de desenvolvimento econômico e social, irradiando progresso para a região.
\end{abstract}

"O espírito bandeirante, conhecedor e explorador dos sertões", como citado acima por Arruda, é uma referência à política de interiorização do governo português na colônia brasileira nos séculos XVII e XVIII por meio da conquista de novas terras "orientadas pelo alargamento e defesa das fronteiras contra os espanhóis" (FELIX, 2008, p. 10). No século XVII bandeirantes paulistas como Manoel de Campos Bicudo e Bartolomeu Bueno da Silva acamparam em São Gonçalo ${ }^{9}$ e iniciaram o mapeamento da região cuiabana. Em 1717 Antônio Pires de Campos e Pascoal Moreira Cabral vieram ao Mato Grosso com a incumbência de aprisionar os índios Coxiponés e, ao atingir o rio Coxipó-Mirim, encontraram ouro de aluvião. O modelo de política do governo português em criar novas vilas perto de fontes de exploração econômica foi retomado no século XX pelo Governo Federal.

"Os empresários do Centro-Sul [...] foram escolhidos para reencarnar o espírito bandeirante" pelo seu o conhecimento em fundar cidades, "alargar fronteiras de nossa Pátria!" Se, a princípio, os sentidos para este moderno bandeirante estiveram destinados ao Colonizador pela mídia oficial, o migrante trabalhador logo resignificou para si o discurso do outro (CERTEAU, 2007). O discurso do progresso foi uma tentativa concreta de reverter o discurso dos "espaços vazios". O migrante se relacionou discursivamente com o que se estava chamando de projeto de colonização do Governo Federal e necessitou construir, ou reconstruir, o significado dado para bandeirante.

Descrever o que era esse "espírito bandeirante" se, por um lado, era um indicador para "explorador dos sertões", como a exploração de índios ou de ouro, por outro lado estava relacionado com a sua coragem. Felix (2008, p. 18) exemplifica:

O padre jesuíta espanhol Antônio Ruiz de Montoya (1585-1652), por exemplo escreveu que os paulistas, a pé e descalços, andavam mais de 2.000 quilômetros por vales e montes 'como se passeassem nas ruas de Madri'. A coragem deles também era extraordinária. Além de terras desconhecidas, sempre enfrentavam terríveis grupos indígenas dispostos à briga. E nem sempre se davam bem. Muitos morreram de forme, em terras estéreis, ou crivados de flechas.

"Como se passeassem nas ruas de Madri" ao andar em meio à floresta também fez parte do colono migrante em sua viagem do Sul ao Mato Grosso, ao abrir suas terras recém-compradas ou pelas ruas barrentas de Sinop. Na biografia de Lindolfo José Trierweiler (SANTOS, 2007, p. 58) temos em exemplo desta jornada quando pararam na cidade de Diamantino:

${ }^{9}$ Hoje Bairro São Gonçalo em Cuiabá - Mato Grosso. 
Lindolfo José Trierweiler e seus amigos de aventura, percorreram as poucas e desertas ruas de Diamantino em busca de um hotel para pernoitar, porém em razão de não haver nenhum hotel na cidade resolvem acampar no pátio da igreja matriz, debaixo de alguns pés de manga. Não demorou muito para que o então padre Henrique Froelich, que tinha vindo do Rio Grande do Sul, futuro bispo de Diamantino e depois Sinop, viesse a ter com os aventureiros e além da alimentação oferecida, contou várias histórias dos índios da região, além de dar informações sobre o Estado de Mato Grosso [...].

A história de Sinop estampada ainda hoje no discurso oficial como a "cidade menina que em breve se tornará metrópole" tomou por base a trajetória dos migrantes vencedores, daqueles que tiveram sucesso, cujos filhos mais tarde se tornariam os 'doutores' da cidade - a história contada é a dos "atores de nome próprio e de brasões sociais" e não dos "figurantes, da multidão de heróis quantificados que perdem nomes e rostos tornando-se a linguagem móvel de cálculos e racionalidades que não pertencem a ninguém" (CERTEAU, 1998, p. 57-58).

O discurso do progresso herdado do processo de colonização no Mato Grosso desde o século XVII foi construído sob a exploração da terra e sua ocupação. Esses bandeirantes do século XX trouxeram consigo o estilo de vida de suas famílias no Sul, como os saberes na lida com a terra, nas construções de casas, na maneira de criar seus filhos, nas profissões e na educação. O sujeito migrante vislumbrou um cenário propício de uma vida melhor na Gleba Celeste.

\section{O sujeito migrante e o discurso do progresso: "a Gleba Celeste acena para o Brasil como novo mundo de riquezas"}

A Gleba Celeste era um mundo verde, dormindo, na solidão da Amazônia. Transformamos o seu rosto, abrindo clareiras e picadas na mata virgem.

E nasceram os primeiros povoados, esperançosas cidades de hoje, crianças ainda, mas correndo, céleres, para o progresso.

E lavradores enfeitaram de roças novas as terras.

E templos de fé passaram a glorificar a Deus.

E o comércio se tornou forte e a

indústria já anuncia rolos de fumaça nas chaminés e gritos de sirenes acordando a distância.

E neste novo mundo, esperançoso e feliz, crianças aprendem as suas primeiras letras e os jovens conquistam bancos colegiais.

Como é bom alargar fronteiras de nossa Pátria! Como é dadivoso o ideal que se enfeita de realizações!

Agora, a Gleba Celeste acena para o Brasil como novo mundo de riquezas e civilização prêmio maior ao nosso ideal de plantar cidades, vendo a terra abrir-se em floradas e anunciar milagres da colheita. (ENIO PIPINO, 1979)

Iniciamos esta seção com um poema do Colonizador Enio Pipino publicado na revista Um passo da conquista da Amazônia de 1979, encomendada pela empresa Colonizadora Sinop para ser divulgada principalmente na Região Sul do país como forma de propagar as cidades da Gleba Celeste.

No poema o Colonizador exalta o feito de adentrar na Floresta Amazônica no início da década de 70, que estava "dormindo", solitária, desabitada, à espera "dos 
primeiros povoados", de ser transformada em terras férteis, oferecendo esperanças de um futuro melhor àqueles que nela viessem habitar. Suas palavras fomentam conquistas em um "novo mundo" onde pelo trabalho, pela fé e pela Pátria "riquezas e civilização" se anunciavam em "milagres da colheita". O ideário mítico dos novos povoadores de Sinop "correndo, céleres, para o progresso", tanto nas cidades abertas na Gleba Celeste quando nas extensões rurais, circulava como um propósito de vida, uma meta a ser alcançada a fim de atingir novas perspectivas econômicas para as famílias que ali chegavam.

Tal poema é um exemplo do que se consolidava nas propagandas para atrair os migrantes: os mitos da terra farta, do progresso, os discursos pontuados e honrados no trabalho, na família, na Pátria, na esperança e no futuro promissor. "Era uma terra de sonho de toda gente, onde se poderia até enricar, seria só ter força de vontade, fé em Deus e mãos à obra, mãe, pai, filho, que todas as dificuldades seriam superadas". (GUIMARÃES NETO, 2002, p. 29, grifo da autora).

No ano de 1972, a empresa Colonizadora publicou na revista VEJA uma matéria sobre o seu projeto de colonização em que descrevia todos os benefícios que estavam sendo preparados para a chegada dos migrantes, os futuros trabalhadores da terra, como: financiamento de material agrícola, uma cooperativa agrícola e comercialização dos produtos. $\mathrm{O}$ "sonho de enricar" se tornava um sonho possível para este migrante que lia matérias com este teor de notícias. A indecisão deixava de ser a regra e a identificação com o projeto do Governo Federal de integração nacional passava a ser visto como uma segurança de emprego garantido e melhoria do padrão de vida.

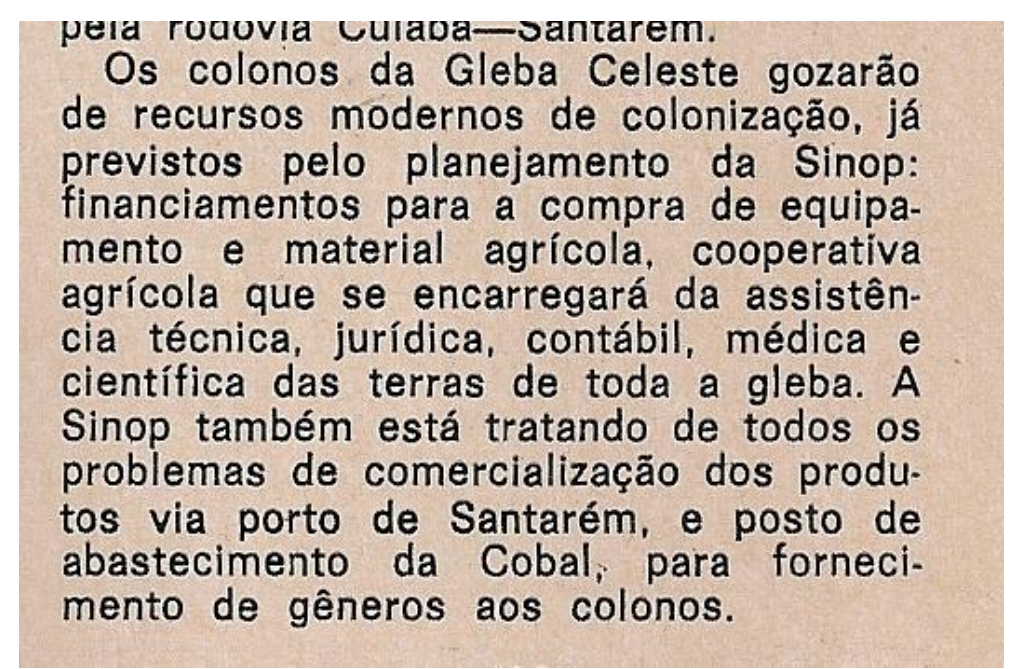

Figura 5 - Matéria publicitária da Colonizadora Sinop S. A.

Fonte: VEJA, São Paulo, n. 205, 9 ago. 1972.

Como sugere Guimarães Neto (2002, p. 149) em análise ao processo de colonização da cidade de Alta Floresta, que também foi fruto de uma colonização privada no norte de Mato Grosso, os discursos do progresso "era uma marca indelével, presente em todos os lugares por onde se passava, direcionando condutas humanas, projetando a esperança no amanhã, refazendo a todo o momento o mito do possível". Segundo a professora Anízia Mendes Gobbo (depoimento 14 jan. 2012) a lembrança dos tempos difíceis foi contida e superada em relação aos momentos de dificuldades, incertezas ou frustrações quando nos fala: "Viemos com tanta vontade de trabalhar, de mudar de vida, 
que nada daquilo me assustou, não tenho lembranças ruins". Diante disso, pode-se inferir que:

O suporte material das lembranças da chegada não mais existe, a imagem da cidade, sob o impacto da velocidade das realizações materiais, substituiu a paisagem que ali haviam encontrado. A "nova terra" não mais se interessa pelo sofrimento passado, a história presente é a do triunfo. Ela vem celebrada pelo fervor do progresso. (GUIMARÃES NETO, 2002, p. 81, grifo da autora)

Habitualmente, as situações difíceis ou as condições desfavoráveis e adversas que foram enfrentadas ficam aquém nas lembranças com o passar dos anos, porém, não são completamente apagadas, mas reaparecem com saudosismo e como marcas de superação, com alegria e bom humor. Isso foi percebido no decorrer do processo de entrevistas com os migrantes - o esquecimento, como sugere Le Goff (1996), é um dos diversos "mecanismos de manipulação da memória coletiva". Assim, diante de uma ideologia que atenda aos interesses de certos grupos, "essa ferramenta é eficaz a partir do momento que ameniza os tempos de dificuldades e privações e conserva na memória a lembrança de conquista de superação" (BONI, 2010, p. 16).

A história do processo colonizatório inundado pelo ideal de progresso se definiu como uma prática em que estavam envolvidos os migrantes, suas relações entre si e com o outro. Colonizador proprietário ou colona professora em seus relatos de vida, em forma de poema ou depoimento, confrontam o agora, esta sua nova vida, com o passado, sua origem, sua antiga vida. E vida, aqui, entendendo-se como uma experiência histórica do sujeito migrante e como ele se fala a partir disso, excluindo ou valorizando acontecimentos. "O relato dessa relação de [...] dominação ou de comunicação com o outro (posto preenchido alternadamente por uma vizinhança ou por um futuro) permite à nossa sociedade contar-se, ela própria, graças à história" (CERTEAU, 2007, p. 55).

O sujeito migrante que aderiu ao discurso do progresso, que ambicionou "enricar" nesta "Gleba Celeste [que] acena para o Brasil como novo mundo de riquezas", no espaço do outro, construiu uma imagem para si de um novo bandeirante. "Esta imagem designa a alteridade intransponível que forma o desejo do sujeito" (CERTEAU, 2007, p. 235). O desejo deste migrante que visava um "mundo de riquezas" com seu trabalho, um novo bandeirante construtor de cidades, não deixou de preocupar-se com a educação escolar de sua família.

Em nenhum momento dos depoimentos estudados os migrantes colocaram na frente suas ambições pessoais em detrimento da educação para os seus. Ao contrário, como veremos a seguir, ter escola para seus filhos era condição de permanência na "terra prometida". O modo como esses pais migrantes se comportaram durante os dois primeiros anos da cidade de Sinop, 1972 e 1973, delineou o modo como as políticas públicas da educação se dariam posteriormente. A luta pelo acesso à educação, formação escolar e qualificação profissional tornou-se um dos princípios do discurso do progresso. 


\title{
A educação e o discurso do progresso: "porque se não tivesse escola para os filhos, o povo não ficava" 10
}

\author{
E foi assim que todo mundo começou... \\ foi uma coisa que começou tão pequeno e que explodiu! \\ Hoje com tantas faculdades, tantas escolas... \\ e pensar que tudo começou naquela salinha de chão batido, \\ de quatro paredes, janela e porta e mais nada. \\ Sem livros, sem materiais, com tantas dificuldades, não tinha nada...
}

E olha como está hoje!

(GUERRA, depoimento jan. 2012)

A primeira professora de Sinop, Terezinha Vandresen Pissinati Guerra, que acompanhou todo o movimento de criação, fundação e desenvolvimento da escola estadual, recorda "que tudo começou naquela salinha de chão batido". No início da colonização, em 1972, não havia escola em Sinop. Em setembro de 1973, a pedido das famílias, a Escola Estadual Perpétuo Socorro, da cidade de Vera na Gleba Celeste, abriu uma pequena sala de aula improvisada, precária, onde faltava tudo, como mencionado nas palavras da primeira professora em epígrafe.

No entanto, as "tantas dificuldades" passadas são relevadas a um segundo plano quando se comparada ao progresso atual: "E olha como está hoje!". Entre 1973 e 2012, data da entrevista com a professora Terezinha, a cidade investiu no campo educacional a ponto de haver, segundo o IBGE (2015) 41 escolas do ensino fundamental, 14 escolas do ensino médio e 31 pré-escolas e 14 instituições de ensino superior ${ }^{11}$ entre públicas e privadas, presenciais ou a distância. O slogan atual da cidade 'Sinop - polo universitário do Nortão'12 ressalta o discurso de uma cidade com formação educacional desde a préescola até a universidade e é veiculado em propagandas nas mídias pública e privada.

Revisitaremos o passado do processo educacional interligada ao discurso de progresso de Sinop a fim de contextualizar o quanto a educação serviu para propagar esse discurso aliado ao desenvolvimento da cidade.

Como pontuado, a maioria dos migrantes eram oriundos do Sul do país e tinham na educação um referencial, "que a escola fazia parte da sua cultura, que 'mandar' os filhos para a escola era uma obrigação da família, e, portanto, caberia aos pais fazê-lo" (PERIPOLLI, 2002, p. 121). O caso da família Trierweiler foi um exemplo de como o fato de ter escolas era importante para manter as famílias na cidade e mais importante do que o "sonho de enricar". Em março de 1973, quando Sinop ainda não tinha escola, a família permaneceu em Cuiabá para que os filhos pudessem estudar. Em dezembro de 1973 mudaram-se para Sinop, mas já no início de 1974 tiveram que se mudar novamente para Vera porque um dos filhos precisava cursar a quinta série (SANTOS, 2007, p. 59). As palavras da ex-professora Anísia Mendes Gobbo (depoimento 14 jan. 2012) reafirmam a

\footnotetext{
10 Palavras retiradas do depoimento da Professora Maria Augusta de Paula em 02 fev. 2012.

11 I Faculdade Fasipe - Fasipe; 2 Universidade Norte do Paraná - Unopar; 3 Centro Universitário Internacional - Uninter; 4 Faculdade Educacional Da Lapa - FAEL; 5 Universidade Paulista - UNIP; 6 Universidade de Cuiabá - UNIC; 7 Centro Universitário de Maringá - Unicesumar; 8 Faculdade Cenecista de Sinop - Facenop; 9 Faculdade de Ciências Sociais Aplicadas de Sinop - Facisas; 10 Faculdade de Ciências Jurídicas, Gerenciais e Educação de Sinop - FIS; 11 Universidade Luterana do Brasil - Ulbra; 12 Universidade do Sul de Santa Catarina - Unisul; 13 Universidade Federal de Mato Grosso - UFMT; 14 Universidade do Estado de Mato Grosso - Unemat. Segundo o site Faculdades Já, 2016.

12 Revista Notícia do Estado de Mato Grosso, 2011.
} 
importância do ato de estudar para esses migrantes: "mesmo os pais vindo para aquele fim de mundo, [...] eles queriam ver seus filhos estudando [...] a educação era o futuro".

Conhecendo a importância da educação para esses migrantes, a empresa Colonizadora confirmava quando consultada que as novas cidades da Gleba Celeste teriam escolas, como no depoimento da professora Anízia de Paula (14 jan. 2012):

O Seu Enio, quando recebia as pessoas na Colonizadora [em Maringá] para comprar terras, ele fazia propagandas, [...], ele falava muito sobre educação, sobre a escola. Para Seu Enio a escola era tudo, então ele incentivava muito as pessoas que vinham aqui, ele falava: "Não, pode ir, seu filho vai ter escola, vai estudar." Ele prometia muito escola, então o pai já vinha ciente de que o filho não ia ficar sem estudar.

A estratégia de oferecer educação aos migrantes era a garantia de oferecer aos filhos dos colonos, a continuação dos estudos e, assim, facilitar a decisão para migrarem para uma região desconhecida, onde tudo estava para se construir, inclusive o sistema educacional escolar, que até então não existia. Os migrantes ao chegarem à pequena cidade em 1972 descobriam que a escola mais próxima se localizava na cidade de Vera, distante 80 quilômetros de Sinop. Para frequentarem a escola as crianças teriam que viajar em uma estrada não pavimentada que ficava intransitável no período chuvoso.

Foi então que, fugindo das "teias da conformidade" (CERTEAU, 1998), os migrantes se organizaram para fazer a escola e "reinventar" aos seus modos o início de um sistema educacional em meio àquele campo aberto na Floresta Amazônica, ainda pouco habitada. Organizados, os migrantes recorreram à Colonizadora, a qual Ihes ofereceu os materiais para a construção de uma sala de aula. De acordo com os depoimentos analisados, a Colonizadora propôs uma troca - forneceria a madeira, telhas de Eternit e outros materiais enquanto aos pais caberia a mão de obra. Não houve outra opção, era preciso construir uma escola, uma vez que sem a escola as pessoas não ficariam na cidade. Assim, em regime de mutirão, os pais:

[...] juntaram-se em uma turma de homens, [...] uma turma de gente, e ali construíram a escola, poucos dias e a escola estava de pé, só que não tinha cimento para fazer o piso, então ficou na terra mesmo, piso de chão batido como alguns falam, se molhava - virava barro, aquele barro branco, grudento; se deixava seco - era aquela poeira. [...] E, foi assim que tudo começou: naquela salinha de chão batido, de madeira, quatro paredes, janela e porta e mais nada, sem livros, sem materiais, com tantas dificuldades, [...] não tinha nada! (GUERRA, depoimento 25 jan. 2012)

Construiu-se, assim, em 1973, a primeira sala de aula, chamada informalmente por alguns migrantes de Grupo Escolar Sinop, como uma extensão da Escola Estadual Nossa Senhora do Perpétuo Socorro, de Vera. Esta parceria entre a sociedade e a Colonizadora se estenderia posteriormente na criação das escolas rurais.

Durante todo o processo de trazer para Sinop uma extensão da escola de Vera a professora Terezinha sempre esteve presente, sendo ela a escolhida para ser a professora desta nova escola. A professora Terezinha Pissinati Guerra (depoimento 25 jan. 2012), ao recordar de quando a procuraram para ser a professora, disse que aceitou devido à insistência dos pais. Ela tinha estudado até a sexta série, no Paraná, e não tinha qualquer experiência no magistério, mas, pelo fato das crianças precisarem estudar, 
decidiu ajudar. Ela foi contratada para ser professora primeiramente pela empresa Colonizadora até que a pequena sala de aula fosse autorizada a funcionar pela Delegacia de Educação e Cultura do Estado de Mato Grosso.

No ano de 1976, através do decreto no 767/76, a extensão da Escola de Vera se tornou oficialmente Escola Estadual Nilza de Oliveira Pipino, nome escolhido pela professora Terezinha Pissinati em homenagem à esposa do Colonizador Enio Pipino. Para direcionar os trabalhos educacionais na Gleba, a Colonizadora Sinop trouxe da cidade de Maringá, do Paraná, especificamente do Colégio Santo Inácio, algumas freiras da Congregação Santo Nome de Maria. As irmãs católicas direcionaram todos os trabalhos que envolviam a educação, saúde e trabalhos sociais, permanecendo até 1986 na Gleba Celeste. Na educação elas exerciam tanto o trabalho de gestão como também de docência.

A educação tornou-se assim instrumento de fixação do migrante à sua nova cidade. Foi um instrumento único que ajudou na formação e qualificação das crianças e adolescentes para o mercado de trabalho, participando do desenvolvimento econômico da cidade, tanto na zona urbana quanto na zona rural. Desde o início, a cada pequena comunidade que surgia aos redores das cidades da Gleba Celeste, uma pequena escola era organizada, as chamadas escolas rurais, geralmente na casa do próprio professor ou professora que, em sua maioria, tinham pouca escolaridade. "E, assim era: onde tivesse 6, 7 alunos, misturava tudo, e dava aula aonde fosse, podia ser na própria casa do professor, já contratava o mais instruído, e funcionava ali uma escola" (BRAZ, depoimento 08 dez. 2011).

Construídas, a princípio, de forma improvisada, sem oferecer estrutura física adequada, materiais didático-pedagógicos para o uso de alunos e professores, as escolas rurais tinham como propósito fundamental manter as novas famílias em suas terras, destinadas principalmente às famílias com filhos em idade escolar. As escolas rurais construídas na época estavam localizadas em pontos importantes dentro comunidade ou em empresas madeireiras: Escola Nossa Senhora da Glória, Escola Ângela, Escola Castanhal (localizava-se em uma comunidade que vivia da coleta da Castanha do Pará), Escola Veridiana, Escola Madelac (localizava-se na Madeireira Madelac), Escola Madenorte (localizava-se na Madeireira Madenorte), Escola Lucília, Escola Silvana, Escola Nilda, Escola Débora, Escola Nossa Senhora de Paula (PERIPOLLI, 2008, p. 151).

No depoimento abaixo temos um exemplo do trabalho conjunto do Secretário de Educação de Mato Grosso e da Colonizadora Sinop, o Estado fornecendo o professor e a Colonizadora construindo a escola, para que os "pais se sentissem seguros" nesta nova cidade:

Em março de 1975 o Osvaldo Sobrinho era Secretário de Educação, ele veio para cá com duas técnicas para orientar todo o trabalho da região, aí fomos todos para um encontro em Vera, e, ele falou com estas palavras, "onde tiver dois ou três alunos e puder fazer uma escola de pau-a-pique eu autorizo o funcionamento e contrato o professor" ele falou assim para todos os pais, imagina a cidade estava começando, todos os pais se sentiram seguros. (BRAZ, depoimento 8 dez. 2011, grifo nosso)

Deste modo, de acordo com o depoimento acima, nos primeiros anos de funcionamento das escolas rurais, a preocupação não era com a formação docente do 
professor, como previa a LDB Lei no 5.692 de 1971, "Art. 77. Quando a oferta de professores, legalmente habilitados, não bastar para atender às necessidades do ensino, permitir-se-á que lecionem, em caráter suplementar e a título precário":
a) no ensino de $1^{\circ}$ grau, até a $8^{\underline{a}}$ série, os diplomados com habilitação para o magistério ao nível da $4^{\underline{a}}$ série de $2^{\circ}$ grau;
b) no ensino de $1^{\circ}$ grau, até a $6^{\underline{a}}$ série, os diplomados com habilitação para o magistério ao nível da $3^{a}$ série de $2^{\circ}$ grau;
c) no ensino de $2^{\circ}$ grau, até a série final, os portadores de diploma relativo à licenciatura de $1^{\circ}$ grau.

As pequenas escolas rurais em torno de Sinop permaneceram todas como extensão da Escola Nilza de Oliveira Pipino. As contratações dos professores eram feitas primeiramente pela Colonizadora e logo depois pelo Estado, quando autorizadas. Nas recordações da Professora Maria Augusta de Paula (depoimento 02 fev. 2012, grifo nosso):

\begin{abstract}
Com o fluxo de pessoas, devido o processo de colonização, vinha muita gente todos os dias. E, para o Seu Enio era obrigatório, não podia ninguém ficar fora da escola, pois era um comprometimento dele - como ele ia vender as áreas, estabelecer o povo aqui e não oferecer a escola? Então, se não tivesse escola para os filhos, o povo não ficava. Na época isto tudo era prometido, tinha que dar escola porque senão, como este povo iria vir e não ter escola?
\end{abstract}

Este breve relato se fez importante para apresentar interesses envolvendo o progresso da região, que para o desenvolvimento econômico estavam intrínsecos à educação naquele momento inicial: em meio a tantas dificuldades de sobrevivência, em um lugar desconhecido, expostos aos perigos da floresta, a falta de subsídios de todos os gêneros, além da saudade dos amigos, parentes e da própria terra natal, as chances de que migrantes retornassem aos seus lugares de origem eram grandes.

Outro fator relevante a ser mencionado tem relação às práticas educativas presentes na escola. Nos depoimentos são notórias as ações que promoviam o civismo, a obediência, a fé, a necessidade de uma educação que preparasse para o trabalho, para o progresso. Segundo o depoimento das professoras Terezinha, Maria Lúcia e Anísia havia inúmeras práticas que fomentavam a religião católica, o patriotismo, como o canto dos hinos Nacional, de Sinop, de Mato Grosso, da Bandeira, assim como o hasteamento da Bandeira Nacional todos os dias antes de iniciar a aula na semana da Pátria.

Também ocorriam muitos desfiles em celebrações cívicas, assim como as inúmeras datas comemorativas, sendo estas sempre muito ensaiadas, organizadas com muita antecedência pelas Irmãs Católicas. Em uma visita no ano de 1978, foi apresentado ao Colonizador um jogral redigido pela professora Maria Lúcia Braz a partir das letras do nome da cidade em que cada letra representava algo que combinasse com o espírito desenvolvimentista de Sinop. Na declamação do jogral, cinco crianças seguravam letras que correspondia ao nome da cidade e um verso era declamado:
S Símbolo de esperança!
I Inspiração para os poetas!
N Namorada de todos os visitantes! 
- Oásis para os deserdados!

P Promessa para um futuro brilhante!

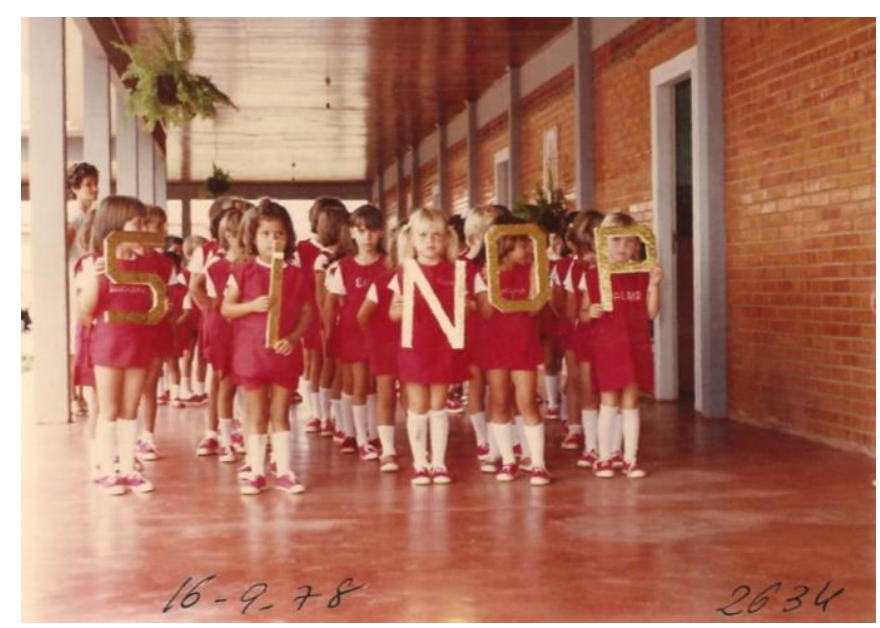

Figura 6 - Alunos da Pré-Escola em homenagens à Sinop.

Fonte: Colonizadora Sinop S. A., Acervo Particular, 16 set. 1978.

Ao final, "cantavam uma musiquinha que era parte do primeiro hino de Sinop, antes do hino oficial, que foi composto por uma das Irmãs: 'A ti Sinop, meiga e gentil, nosso pleito, nossa ovação. Tu és semente de mil progressos, és futuro da nação'." Com isso, as práticas cívico-patrióticas em voga na escola "atendiam assim, a múltiplos propósitos: fosse a perpetuação da memória histórica nacional, a exibição das virtudes morais e cívicas inscritas na obra formativa escolar, a ação educadora da escola para o conjunto da sociedade" (SOUZA, 2000, p. 116).

As práticas mencionadas e a cultura produzida pela escola se voltam para o que Julia (2001) define como um conjunto de normas que determinam conhecimentos a ensinar e condutas a inculcar, um conjunto de práticas que permite a transmissão desses conhecimentos e a incorporação de comportamentos. Um conjunto de práticas, normas, conhecimentos e condutas, aparentemente normais, porém repletas de intencionalidade, de "estratégias" (CERTEAU, 1998) que buscavam moldar a criança para que, futuramente, assim como seus pais, se comportassem de forma a provar o sentimento de brasilidade, o temor a Deus e à Pátria.

Em 1978 a Escola Nilza de Oliveira Pipino passou a ter $2^{\circ}$ grau com a introdução progressiva dos cursos de Magistério, a fim de qualificar profissionais para atender as inúmeras escolas de $1^{\underline{a}}$ a $4^{a}$ séries, Contabilidade, para atender às indústrias e comércios em geral, e Análises Químicas. Com o 2o grau completo a Escola Nilza passou a chamarse Centro Educacional.

No cenário do projeto de colonização de Sinop, a seleção dos cursos profissionalizantes era, também, questão de políticas públicas. A escolha pelo curso de Análises Químicas é um exemplo do quanto a empresa Colonizadora, em conjunto com o trabalho educacional da Igreja Católica (na figura das Irmãs), atuava e participava do processo de colonização e fixação deste morador à terra. Agora não mais em ter escolas de $1^{\circ}$ grau para fixar as famílias (pais e crianças) na nova cidade como ocorrera no início de 1973, mas a nova necessidade era ter escolas profissionalizantes para fixar estes 
adolescentes a partir de sua qualificação para o trabalho.

Durante o ano de 1978 o Colonizador Sr. Ênio Pipino ${ }^{13}$ emitiu ofícios à Delegacia Estadual de Educação de Mato Grosso em que solicitava a implantação do curso técnico, com habilitação em Análises Químicas. A razão da escolha era a formação de técnicos para atuarem na Sinop Agroquímica (SAQ), uma das empresas do projeto de colonização que se destinava à produção de etanol proveniente da mandioca, e tinha como objetivo promover a industrialização dos produtos agrícolas para atender o mercado local e de fora (OLIVEIRA, 1983). As cartas a seguir, de 26 de outubro de 1978, do Colonizador Enio Pipino para a Irmã Edita, responsável à época por toda a educação na Gleba Celeste, noticiou sua solicitação ao Secretário de Educação para a criação do curso de Análises Químicas, o qual atenderia às expectativas da Sinop Agroquímica ${ }^{14}$ :

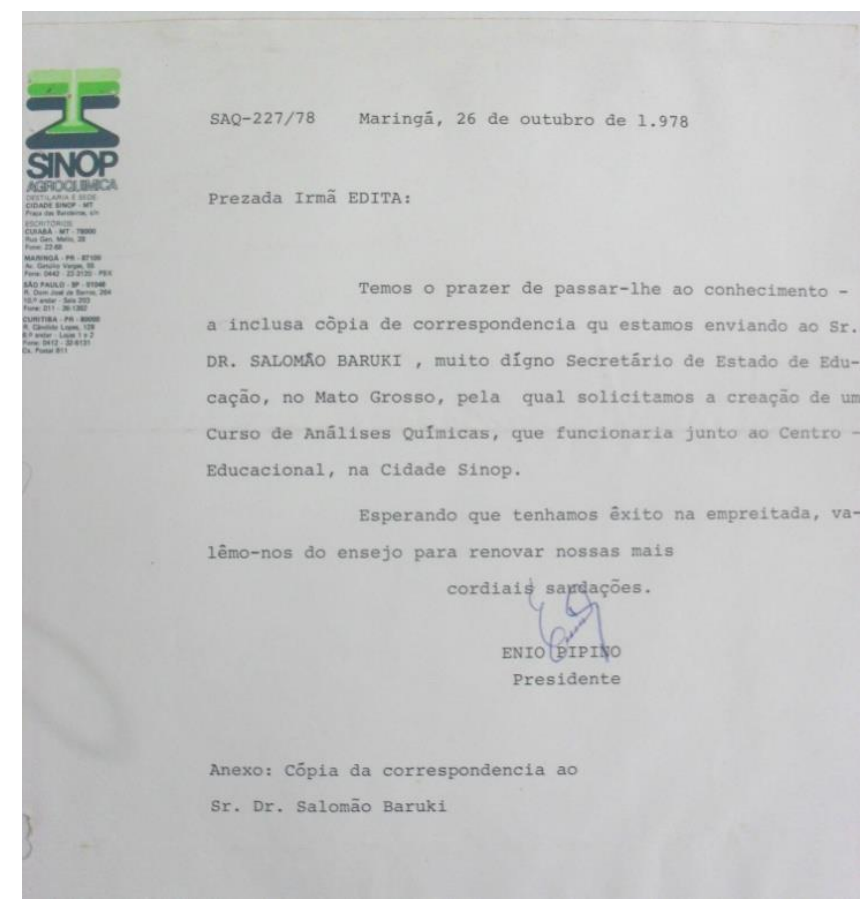

Figura 7 - Carta do Colonizador Enio Pipino à Irmã Edita.

Fonte: Escola Estadual Nilza de Oliveira Pipino, 1978.

${ }^{13}$ Vários ofícios se encontram guardados na Escola Nilza de Oliveira Pipino sobre pedidos do Colonizador Enio Pipino para a contratação de professores, para o envio de materiais didáticos ou mesmo solicitações de mudança de nível escolar.

14 De acordo com Pereira (2007), com a crise do álcool, na década de 1980, os planos da Sinop Agroquímica, cuja pretensão era produzir 50 milhões de litros de álcool por ano, foram obstaculados. 


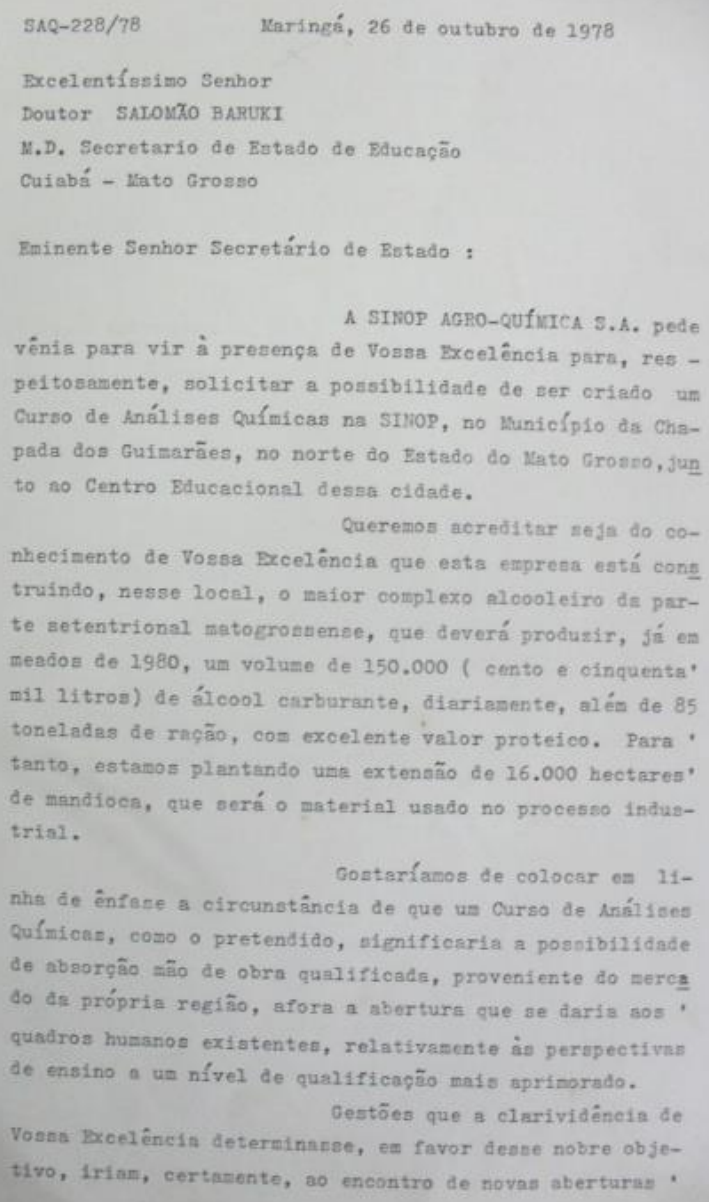

Figura 8 - Correspondência enviada pelo Colonizador ao Secretário de Educação do Estado.

Fonte: Escola Estadual Nilza de Oliveira Pipino, 1978.

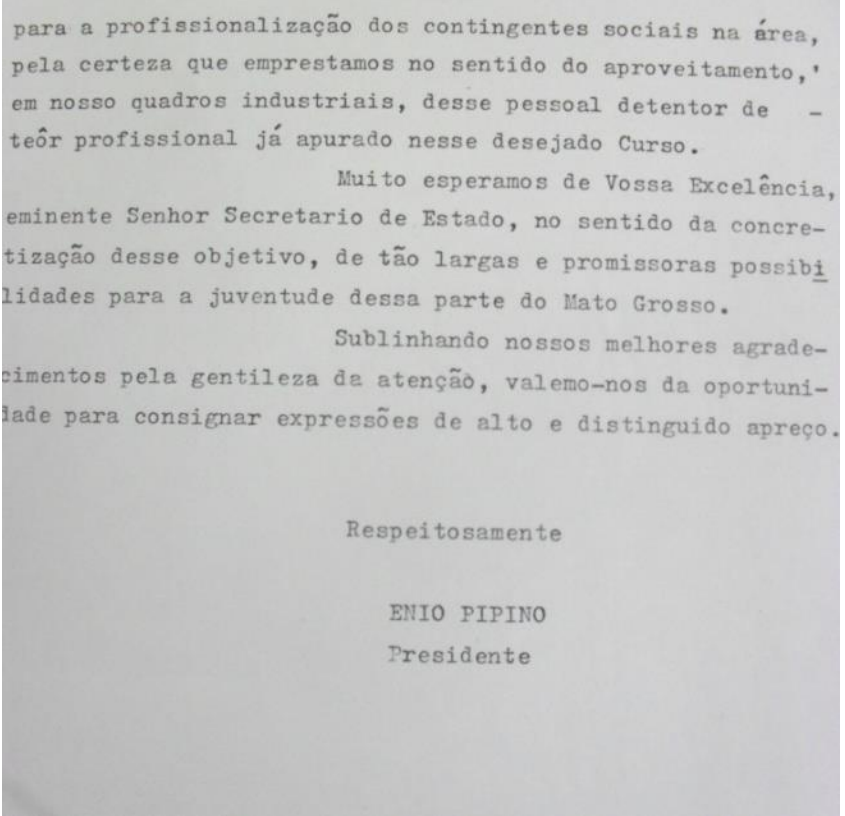

Figura 9 - Trecho da correspondência enviada pelo Colonizador ao Secretário de Educação do Estado.

Fonte: Escola Estadual Nilza de Oliveira Pipino, 1978. 
Assim, no ano de 1979, a solicitação do Colonizador foi atendia pelo então Secretário de Educação do Estado Salomão Baruki com o início do curso de Análises Químicas. O Colonizador justificou sua criação como uma necessidade "de absorção de mão de obra qualificada, proveniente do mercado da própria região". Para o sucesso do projeto de colonização, educação e trabalho foram pontos coordenados com muita atenção pela empresa Colonizadora, tanto em 1973 quanto em 1979.

No início da década de 70, os migrantes vieram trabalhar na abertura das terras e em empregos urbanos, trazendo consigo suas famílias. A necessidade de escolas era tanta que este foi um fator determinante para a permanência da família no local. No final da década, as famílias pioneiras já tinham seus filhos adolescentes e prontos para entrarem no mercado de trabalho. A cidade apresentava carência de profissionais qualificados em várias áreas importantes e se tornava urgente sanar estas brechas: para o comércio e empresas faltavam contabilistas, para as escolas professores, e para a indústria química, técnicos em Análises Químicas.

Como dissemos anteriormente, o modo como os pais migrantes se comportaram durante os dois primeiros anos da cidade de Sinop, 1972 e 1973, delineou o modo como as políticas públicas da educação se dariam posteriormente. As solicitações dos pais para a abertura de escolas, a intervenção da Colonizadora junto à Secretaria de Educação do Mato Grosso, a condução das Irmãs na didática e nos conteúdos escolares, sociedadeestado-igreja, todas as entidades, todas as ações realizadas, contribuíram para que Sinop hoje, século XXI, fosse considerada um polo educacional.

Em 17 de dezembro de 1979, pela Lei Estadual 4.156/79, criou-se o Município de Sinop. A partir deste momento, a cidade passou a ter Secretaria de Educação própria, gradativamente desvinculando a educação de um contexto religioso.

\section{Considerações finais}

Estudarmos a cidade de Sinop entre 1973 e 1979 é lembrarmos-nos de Certeau (2007, p. 44) quando nos fala que "A organização ontem viva de uma sociedade, investida na ótica de seus historiadores, se transforma, então, num passado suscetível de ser estudado." Tendo o discurso do progresso como elemento agregador, partimos em uma linha de análise que iniciou pelo processo de colonização, passando pelo sujeito migrante para chegarmos à educação escolar.

A autora Guimarães Neto (2002, p. 163, grifos da autora) enfatiza que as lembranças dos migrantes no processo colonizatório, seus desejos e esperanças, medos, revoltas, enfim, as suas experiências, foram substituídas pela marcha do progresso:

O sonho da terra prometida teve seus fragmentos transpostos para um tempo indefinido, para algum canto de um tempo sem fim. Destituíram os referenciais que marcaram os "tempos difíceis e instituíram os sinais codificados de uma história linear, em que cada acontecimento passado é demonstrativo de uma só trajetória: a construção da cidade pelas aquisições contínuas do progresso".

Ao significar este processo "pelas aquisições contínuas do progresso", pelo lado oficial para o Estado e para o Colonizador, permaneceu na imagem do passado, daquilo 
que caracterizou o início do progresso como um "ideal que se enfeita de realizações!" 15 Pelo lado dos migrantes, o crescimento da cidade levou ao esquecimento "das feridas passadas, que restam apenas como cicatrizes, sulcos na terra, por onde desabrocham, ou abortam as luzes do progresso" (GUIMARÃES NETO, 2002, p. 81). Como nos lembra a professora Maria Lúcia Braz (depoimento 8 dez. 2011) quando descreve o crescimento urbano de Sinop "[...] sempre foi um crescimento acelerado, até me assusta! Me parece que Sinop não nasceu, ela explodiu!"

A relação entre o discurso do progresso e a educação em Sinop foi abordada dentro do contexto de uma política de integração nacional de ocupação dos espaços demográficos considerados vazios no Mato Grosso. Estes espaços foram sendo ocupados pela frente pioneira, neste processo colonizatório, que transferiu grande contingente populacional vindo de outras unidades federativas em direção às terras preparadas anteriormente pelas frentes de expansão. Buscamos direcionar um olhar para o cotidiano deste processo de educação escolar considerando as histórias que não são contadas pela História Oficial, de modo a compreender que "[...] existe em cada história um processo de significação que visa sempre preencher o sentido da história: 0 historiador é aquele que reúne menos os fatos do que os significantes" (CERTEAU, 2007, p. 52).

A educação escolar, em tal momento, serviu como um instrumento do discurso desenvolvimentista que era a proposta político-econômica brasileira do governo militar da década de 70. O depoimento da Professora Maria Augusta de Paula (02 fev. 2012, grifo nosso) marca como se dava esta relação entre o haver e o não haver escola dentro do discurso de integração nacional:

E o comércio do Seu Enio dependia disto. Também, como ele vendia os lotes não só na cidade, como também fora, na área rural, muita gente comprava estes lotes e ia para o sítio. As comunidades iam se formando e com elas várias escolinhas iam se formando, porque não podia deixar ninguém sem estudar. Porque se não tivesse escola o povo não ficava.

A não fixação do migrante naquelas terras significava o risco de fracasso do projeto de colonização do Governo Federal, que intencionava, sobretudo, agregar os espaços destinados para a colonização à economia nacional. A probabilidade de retorno destes migrantes era alta, o que causaria um agravo ainda maior na economia de seus estados de origem pelo número de trabalhadores excedentes e pelos conflitos de terras já lá existentes.

"E o comércio do Seu Enio dependia disto", do haver escolas na cidade e na área rural, uma condição para que as vendas de terras da Colonizadora aos sulistas ocorressem. Assim, um ano antes da cidade ser fundada oficialmente, a extensão da Escola Estadual de Vera já estava aberta em Sinop e pequenas escolas rurais multisseriadas começavam a ser criadas na zona rural.

E a escola da professora Maria Lúcia, como das outras professoras aqui apresentadas, era o local de propagar o discurso do progresso, principalmente pelas práticas do cotidiano escolar quando se tornava mais visível. No depoimento da professora Maria Lúcia Braz (depoimento 2011, grifo nosso), tivemos o testemunho de

15 Fragmentos do Poema Enio Pipino, 1979. 
que todas as vezes que alguma autoridade chegava à cidade, a pedido do Colonizador Enio Pipino, eram feitas algumas apresentações pela escola: "Seu Enio gostava de mostrar como a escola estava progredindo. Ele via na educação o progresso da cidade".

O haver escola na cidade foi também imperativo para que valores de amor à Pátria fossem ressaltados, pelo trabalho duro, pela bravura dos "modernos bandeirantes" que abriram picadas na floresta e construíram cidades, valores representativos do discurso do progresso. E, neste discurso, a cidade menina de Sinop se tornou um polo educacional, acenando "para o Brasil como novo mundo de riquezas e civilização"16.

\section{Referências}

ARRUDA, Zuleika Alves. Sinop: território(s) de múltiplas e incompletas reflexões. 1997. 183 f. Dissertação (Mestrado em História) - Universidade Federal do Pernambuco, Recife, 1997.

AS 20 METRÓPOLES brasileiras do futuro: Sinop, a capital do Nortão. VEJA, São Paulo: Abril, Matéria Especial n. 2.180, 01 set. 2010.

BONI, Márcia Regina. Histórias e Trajetórias de vida de professoras migrantes no município de Sorriso/MT. 2010. 115 f. Dissertação (Mestrado em História) - Instituto de Ciências Humanas e Sociais, Universidade Federal de Mato Grosso, Cuiabá, 2010.

BRASIL. Lei n 5.692, de 11 de agosto de 1971. Lei de Diretrizes e Bases da Educação Nacional. Fixa Diretrizes e Bases para o Ensino de $1^{\circ}$ e $2^{\circ}$ graus, e dá outras providências. Diário Oficial [da] República Federativa do Brasil, Brasília, DF, 12 ago. 1971. Disponível em: <http://www.presidencia.gov.br/ccivil_03/Leis/L5692.htm>. Acesso em: 19 jan. 2006.

BRAZ, Maria Lúcia. Maria Lúcia Braz: depoimento [8 dez. 2011]. Entrevistadora: Josiane Brolo Rohden, Sinop-MT, 2011. 1 gravador de áudio (2h 07min). Entrevista concedida para a Dissertação de Mestrado sobre a História da Educação de Sinop-MT entre 1973 e 1979.

BRUNETTI, Antonio. Paranaenses aceitam o desafio para a ocupação da Amazônia. $O$ Estado do Paraná, Curitiba, 15 maio 1975. Especial.

CERTEAU, Michel de. A Escrita da História. Tradução de Maria de Lourdes Menezes. Rio de Janeiro: Forense-Universitária, 2007.

A invenção do cotidiano: artes de fazer. Tradução de Ephraim Ferreira Alves. 4. ed. Petrópolis: Vozes, 1998, v.1.

COLONIZADORA SINOP S.A. Vista aérea de Sinop. 1979. 1 fotografia color., tamanho original $11 \mathrm{~cm} \times 15 \mathrm{~cm}$.

Alunos da Pré-Escola em homenagens à Sinop. 1978. 1 fotografia color., tamanho original $11 \mathrm{~cm} \times 15 \mathrm{~cm}$.

. Abertura de Sinop, pela Colonizadora Sinop. 1972. 1 fotografia p\&b, tamanho original $11 \mathrm{~cm} \times 15 \mathrm{~cm}$.

. Panfleto Publicitário: frente e verso. Década de setenta e oitenta. 2 fotografias, p\&b, tamanho original $11 \mathrm{~cm} \times 15 \mathrm{~cm}$.

ESCOLA ESTADUAL NILZA DE OLIVEIRA PIPINO. Cartas de notificação do curso de Análises Químicas. Sinop, 1979.

16 Poema de Enio Pipino, revista Um passo da conquista da Amazônia de 1979. 
FACULDADES JÁ. Cidades: Sinop. Disponível em:

<http://faculdadesja.com.br/faculdades/cidades/sinop-mt>. Acesso em: 22 jul. 2016.

FELIX, Pedro Carlos Nogueira. História de Mato Grosso: dos primeiros tempos a atualidade. Cuiabá: Defanti Editora, 2008.

GOBBO, Anízia Mendes. Anízia Mendes Gobbo: depoimento. [14 jan. 2012]

Entrevistadora: Josiane Brolo Rohden, Sinop 2012. Gravação digital (2h 06seg).

Entrevista concedida para a pesquisa sobre a História da Educação em Sinop, Mato

Grosso.

GUERRA, Terezinha Vandresen Pissinati. Terezinha Vandresen Pissinati Guerra: depoimento. [25 jan. 2012] Entrevistadora: Josiane Brolo Rohden, Sinop 2012. Gravação digital (1h 26min). Entrevista concedida para a pesquisa sobre a História da Educação em Sinop, Mato Grosso.

GUIMARÃES NETO, Regina Beatriz. A lenda do ouro verde: política de colonização no Brasil contemporâneo. Cuiabá: UNICEN, 2002.

IBGE. Mato Grosso. Sinop: ensino - matrículas, docentes e rede escolar - 2015. Disponível em: <http://cod.ibge.gov.br/17VV5>. Acesso em: 22 jul. 2016.

INICIATIVA particular coloniza a Amazônia. VEJA, São Paulo, Abril, n. 205, 9 ago. 1972.

JULIA, Dominique. A cultura escolar como objeto Histórico. Tradução Gisele de Souza. Revista Brasileira de História da Educação, Campinas, n. 1, p. 9- 44, 2001.

LE GOFF, Jacques. História e memória. Tradução de Bernardo Leitão. 4. ed. Campinas: EdUNICAMP, 1996.

OLIVEIRA, João Mariano de. A Esperança vem na frente: contribuição ao estudo da pequena produção em Mato Grosso, o caso de Sinop. São Paulo: USP, 1983. 144 f. Dissertação (Mestrado em Geografia) - Departamento de Geografia da Faculdade de Filosofia, Letras e Ciências Humanas, Universidade de São Paulo.

PANOSSO NETTO, Alexandre. Vera - a princesinha do Nortão: uma contribuição ao estudo da ocupação da Amazônia mato-grossense. Campo Grande, MS: Impressão Gráfica União-Rondonópolis, MT, 2000.

PAULA, Maria Augusta de. Maria Augusta de Paula: depoimento. [02 fev. 2012] Entrevistadora: Josiane Brolo Rohden, Sinop, 2011. Gravação digital (1h 38min 05seg). Entrevista concedida para a pesquisa sobre a História da Educação em Sinop, Mato Grosso.

PERIPOLLI. Odimar João. Expansão do capitalismo na Amazônia Norte Mato-grossense: a mercantilização da terra e da escola. Porto Alegre: UFRGS, 2008. $267 \mathrm{f}$. Tese (Doutorado em Educação). Faculdade de Educação, Universidade Federal do Rio Grande do Sul, Porto Alegre, 2008.

Amaciando a terra - O projeto casulo: um estudo sobre a política educacional dos projetos de colonização do Norte de Mato Grosso. Porto Alegre: UFRGS, 2002. $182 \mathrm{f}$. Dissertação (Mestrado em Educação) - Faculdade de Educação, Universidade Federal do Rio Grande do Sul.

REVISTA NOTÍCIA DO ESTADO DE MATO GROSSO. Sinop 37 anos. Porto Alegre: PRC LTDA, ed. 106, Ano XVII, out. 2011.

SANTOS, Luiz Erardi F. Raízes da História de Sinop. Arte Design: Sinop, 2007.

SIQUEIRA, Elizabeth Madureira; COSTA, Lourença A. da; CARVALHO, Cathia M. C. O Processo histórico de Mato Grosso. 3. ed. Cuiabá: Guaicurus, 1990. 
SÓ GEOGRAFIA. Mapa estado de Mato Grosso. Disponível em:

<http://www.sogeografia.com.br/Conteudos/Estados/MatoGrosso/>. Acesso em: 16 jan. 2017.

SOUZA, Edison Antônio de. Sinop - História, Imagens e Relatos: um estudo sobre a sua colonização. 2. ed. Cuiabá: EdUFMT, 2006.

SOUZA, Rosa Fátima de. A militarização da infância: Expressões do nacionalismo na cultura brasileira. Cadernos Cedes, ano XX, n. 52, p. 104-121, 2000. Disponível em: <http://www.scielo.br/pdf/ccedes/v20n52/a08v2052.pdf>. Acesso em: 19 mar. 2012.

STRAUB, S. L. W. Estudo da nomeação das cidades que compõem a Gleba Celeste (MT). In: Dias M. P. de L.; Philippsen, N. I.; Straub, S. L. W.; Oliveira T. P. Amazônia: Visão Caleidoscópica. Recife: Pipa Comunicação, 2015. p. 149-172.

TEIXEIRA, L. A colonização no Norte de Mato Grosso: o exemplo da Gleba Celeste. 2006. 118 f. Dissertação (Mestrado em Geografia) - Universidade Estadual Paulista, Presidente Prudente, 2006.

UM PASSO DA CONQUISTA DA AMAZÔNIA: a realidade da Gleba Celeste. Material de Divulgação da Colonizadora Sinop S. A. 5. ed. Maringá: Grupo Sinop, 1979.

CRISTINNE LEUS TOMÉ é professora na Universidade do Estado de Mato Grosso (Unemat), Doutora em Educação pela Universidade Federal do Rio Grande do Sul (Ufrgs).

Endereço: Rua dos Barús, 42 casa 01 - 78550-130 - Sinop/MT - Brasil

E-mail: cristinne@unemat-net.br

JOSIANE BROLO ROHDEN é professora na Universidade Federal de Rondônia (UNIR), doutoranda em Educação pela Universidade Federal de Mato Grosso (UFMT). Endereço: Rua das Perobas, 377 - Jardim das Palmeiras - 78552-057 - Sinop/MT - Brasil E-mail: josib_rohden@hotmail.com

Recebido em 25 de agosto de 2016.

Aceito em 04 de janeiro de 2017. 